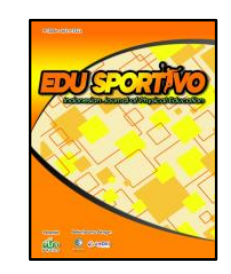

\title{
Implementasi metode bagian dalam meningkatkan keterampilan servis forehand tenis meja
}

\section{Implementation of the inner method in improving table tennis forehand service skills}

\section{Dedy Effendy, *2Merlina Sari, ${ }^{3}$ Ricky Fernando, ${ }^{4}$ Muspita}

1 Sekolah Menengah Pertama Muhammadiyah 2, Pekanbaru, Indonesia

*2,3,4 Pendidikan Jasmani Kesehatan dan Rekreasi, Universitas Islam Riau, Pekanbaru, Indonesia

Received: 16 June 2020; Accepted 03 December 2020; Published 04 December 2020

OPENOACCESS

\begin{tabular}{|c|c|}
\hline ABSTRAK & ABSTRACT \\
\hline $\begin{array}{l}\text { Tujuan yang ingin dicapai dalam penelitian ini adalah untuk } \\
\text { meningkatkan meningkatkan keterampilan servis forehand } \\
\text { tenis meja siswa. Penelitian ini merupakan penelitian tindakan } \\
\text { kelas. Lebih khusus penelitian ini adalah penelitian tindakan } \\
\text { kelas kolaboratif, yaitu kerjasama antara peneliti dengan } \\
\text { praktisi lapangan (Guru). Penelitian ini terdiri dari beberapa } \\
\text { siklus, masing-masing siklus melalui tahap, perencanaan } \\
\text { tindakan, pelaksanaan tindakan, observasi dan refleksi. Subjek } \\
\text { penelitian ini adalah siswa kelas VIII1 SMP Muhammadiyah } 2 \\
\text { Pekanbaru sebanyak } 27 \text { siswa. Penelitian ini menggunakan } \\
\text { perangkat pembelajaran dan instrumen pengumpulan data } \\
\text { rubrik unjuk kerja keterampilan servis forehand tenis meja. } \\
\text { Berdasarkan hasil penelitian dan pembahasan, maka dapat } \\
\text { ditarik kesimpulan bahwa penerapan metode bagian dapat } \\
\text { meningkatkan keterampilan servis forehand tenis meja siswa } \\
\text { kelas VIII1 SMP Muhammadiyah } 2 \text { Pekanbaru. Dimana dari } 27 \\
\text { orang siswa sudah menunjukkan hasil yang baik dimana } \\
\text { bertambahnya jumlah anak yang mampu mencapai atau } \\
\text { melewati nilai acuan patokan minimal (KKM). Berdasakan } \\
\text { temuan penelitian ini, diharapkan guru pendidikan jasmani } \\
\text { bisa menjadikan metode bagian salah satu solusi dalam } \\
\text { meningkatkan keterampilan servis forehand tenis meja. }\end{array}$ & $\begin{array}{l}\text { The aim of this research is to improve students' table tennis } \\
\text { forehand service skills. This research is a classroom action } \\
\text { research. More specifically, this research is collaborative } \\
\text { classroom action research, namely collaboration between } \\
\text { researchers and field practitioners (teachers). This study } \\
\text { consisted of several cycles, each cycle through stages, action } \\
\text { planning, action implementation, observation and reflection. } \\
\text { The subjects of this study were } 27 \text { students of class VIIII SMP } \\
\text { Muhammadiyah } 2 \text { Pekanbaru. This study used learning tools } \\
\text { and data collection instruments for the performance rubric of } \\
\text { table tennis forehand service skills. Based on the results of } \\
\text { research and discussion, it can be concluded that the } \\
\text { application of the part method can improve the table tennis } \\
\text { forehand service skills of class VIIII students of SMP } \\
\text { Muhammadiyah } 2 \text { Pekanbaru. Where from } 27 \text { students have } \\
\text { shown good results where an increase in the number of } \\
\text { children who are able to reach or pass the minimum } \\
\text { benchmark reference value (KKM). Based on the findings of } \\
\text { this study, it is hoped that physical education teachers can } \\
\text { make the method part of a solution in improving table tennis } \\
\text { forehand service skills. }\end{array}$ \\
\hline Kata Kunci: Servis; Forehand; Tenis Meja; Metode Bagian & Keyword: Service; Forehand; Table Tennis; Method Part \\
\hline $\begin{array}{l}\text { *Corresponding Author } \\
\text { Email: merlinasari@edu.uir.ac.id }\end{array}$ & doi https://doi.org/10.25299/es:ijope.2020.vol1(2).5145 \\
\hline
\end{tabular}

How To Cite: Effendy, D., Sari, M., Fernando, R., \& Muspita. (2020). Implementasi metode bagian dalam meningkatkan keterampilan servis forehand tenis meja. Edu Sportivo: Indonesian Journal of Physical Education, 1(2), 79-87. https://doi.org/10.25299/es:ijope.2020.vol1(2).5145

\section{PENDAHULUAN}

Pendidikan merupakan suatu proses pembinaan manusia yang berlangsung selama seumur hidup (Taufik \& Gaos, 2019). Pendidikan berintikan interaksi antara pendidik dengan peserta didik dalam upaya membantu peserta didik menguasai tujuan-tujuan pendidikan. Interaksi pendidikan dapat berlangsung dalam lingkungan keluarga, sekolah, ataupun masyarakat (Nurfajrin, 2014). Pendidikan adalah pengalaman-pengalaman terprogram dalam bentuk pendidikan formal, non-formal, dan, informal di sekolah 
maupun luar sekolah yang berlangsung seumur hidup. Hal tersebut bertujuan optimalisasi pertimbangan kemampuan-kemampuan individu, agar dikemudian hari dapat memainkan peranan hidup secara tepat (Mudyahardjo, 2012).

Pendidikan jasmani merupakan program dari bagian pendidikan umum yang memberi kontribusi terhadap pertumbuhan dan perkembangan anak secara menyeluruh yaitu fisik, gerak, mental dan sosial (Haris, 2018). Pendidikan jasmani adalah salah satu mata pelajaran yang ada di setiap sekolah (Hasrion, Sari, \& Gazali, 2020), dan merupakan mata pelajaran yang memang sangat digemari siswa. Pada proses pembelajaran teknik yang dilakukan oleh para guru diharapkan dapat memberikan sumbangan yang berarti terhadap penampilan siswa dalam permainan. Dalam pembelajaran secara teknik orientasi pengajarannya cenderung menekankan pada perintah atau guru lebih memegang kendali (otoriter) dalam menginstruksikan tugas gerak pada peserta didik. Dalam faktanya pembelajaran teknik yang diterapkan hanya sebagai salah satu strategi dalam pengajaran yang disajikan pada tahap awal proses latihan belajar gerak dengan memberikan perintah pada siswa (teaching centered). Dari sisi ilmu faal olahraga keterampilan teknik kemampuan melakukan gerakan-gerakan keterampilan suatu cabang olahraga dari mulai gerak keterampilan yang tersulit, termasuk gerak-tipu yang menjadi ciri cabang olahraga tersebut (Giriwijoyo, 2012). Pendidikan jasmani dan olahraga memiliki dua keuntungan utama yaitu keuntungan fisik dan edukasi (Widiyatmoko \& Hudah, 2017). Aktifitas jasmani pada dasarnya merupakan kebutuhan setiap manusia di dalam kehidupannya agar kondisi fisik dan kesehatannya tetap terjaga dengan baik. Akan tetapi, dimana sekarang ini menuntut manusia akan lebih banyak menghabiskan waktunya untuk bekerja. Dengan kondisi yang demikian, olahraga menjadi sesuatu yang jarang dilakukan, jika hanya bisa dilakukan dalam waktu luang siang hari (Mubarok, 2015).

Keterampilan teknik merupakan hasil dari proses belajar dan berlatih gerak yang secara khusus ditujukan untuk menampilkan mutu tinggi cabang olahraga itu. Salah satu mata pelajaran permainan pada pendidikan jasmani adalah tenis meja. Permainan tenis meja merupakan salah satu cabang olahraga yang banyak digemari oleh masyarakat luas. Tenis meja dapat dimainkan dan dapat dinikmati oleh semua anggota keluarga, memberi gerak badan serta hiburan kepada pemain-pemain semua tingkat usia, baik usia dini, remaja, maupun dewasa (Mahendra, Nugroho, \& Junaidi, 2012). Melalui olahraga ini juga dapat mendidik siswa untuk rajin, tekun, ulet, disiplin dan bertanggung jawab (Saripin, Agust \& Rafni dalam Sari \& Antoni, 2020).

Salah satu teknik dasar dalam permainan tenis meja adalah servis forehand. Pukulan forehand merupakan latihan pukulan dasar pertama pada permainan tenis meja (Juniarisca dan Andrijanto, 2017). Selain itu pukulan forehand adalah teknik serangan utama dalam permainan tenis meja (Huang, Hsueh, Chen, Chang, Pan, Huang, \& Tsai, 2012). Pukulan forehand adalah sebuah pukulan teknik dasar tenis meja dimana posisi telapak tangan yang memegang bet menghadap ke depan saat memukul bola. Posisi atau sikap bet saat memukul bola, tangan dan siku membentuk sudut 90 derajat, maka posisi bet tersebut tegak lurus (Juniarisca \& Andrijanto, 2017). Dalam melakukan pukulan forehand terdapat beberapa tahapan, yaitu: (1) sikap awalan gerakan lengan, (2) gerakan memukul gerakan lengan, (3) sikap akhir gerakan lengan (Juniarisca \& Andrijanto, 2017). Dalam permainan tenis meja, kecepatan awal bola dari pukulan forehand lebih cepat lebih cepat daripada drive backhand. Pukulan forehand tidak sulit apabila diajarkan dengan cara yang benar, menarik, dan menyenangkan (Reza \& Kartiko 2019). Untuk melaksanakan proses belajar mengajar yang baik pada pelajaran tenis meja maka guru harus memikirkan metode yang cocok buat peserta didik. Untuk mempermudah siswa 
dalam melaksanakan praktik servis salah satunya metode yang digunakan adalah metode bagian.

Metode bagian "part method" adalah suatu cara mengajar yang beranjak dari suatu bagian ke keseluruhan, atau dari yang khusus ke umum (Suryani, 2017). Metode bagian atau part method merupakan bentuk latihan keterampilan yang dilakukan secara bagian perbagian dari keterampilan yang dipelajari. Caranya dimulai dengan mengajarkan bagian-bagian terkecil dari suatu keterampilan dan akhirnya dibangun menjadi suatu keterampilan yang utuh (Prastowo, 2014). Metode bagian atau part method merupakan bentuk latihan keterampilan yang dilakukan secara bagian perbagian dari keterampilan yang dilakukan secara bagian perbagian dari keterampilan yang dipelajari. Bentuk keterampilan pembelajaran dipilah - pilah ke dalam bentuk gerakan yang lebih efisien dan sederhana (Putro, 2016). Berbagai riset menunjukkan bahwa bagian-bagian lebih mudah dan lebih cepat dapat dipelajari, dan siswa akan merasa lebih puas dan lebih percaya diri bila nanti harus melakukan gerak keseluruhan (Harsono, 2015).

Observasi yang dilakukan oleh peneliti pada siswa masih banyak siswa yang belum mampu melakukan teknik dasar servis forehand dengan baik dan benar. Sulit mengatur posisi dari anggota tubuh bagian lengan. Berdasarkan uraian di atas penulis tertarik mengadakan suatu kajian ilmiah yang bertujuan untuk melihat peningkatan keterampilan belajar servis forehand tenis meja dengan menggunakan metode bagian pada siswa.

\section{METODE PENELITIAN}

Penelitian ini merupakan penelitian tindakan kelas. Lebih khusus penelitian ini adalah penelitian tindakan kelas kolaboratif, yaitu kerjasama antara peneliti dengan praktisi lapangan (Guru). Penelitian ini terdiri dari beberapa siklus, masing-masing siklus melalui tahap, perencanaan tindakan, pelaksanaan tindakan, observasi dan refleksi. Subjek penelitian ini adalah siswa kelas VIII1 SMP Muhammadiyah 2 Pekanbaru sebanyak 27 siswa. Penelitian ini menggunakan perangkat pembelajaran dan instrumen pengumpulan data rubrik unjuk kerja keterampilan servis forehand tenis meja. Adapun prosedur atau langkah-langkah Penelitian Tindakan Kelas (PTK) yang mengacu pada Arikunto (2015) dapat dilihat pada gambar 1 .

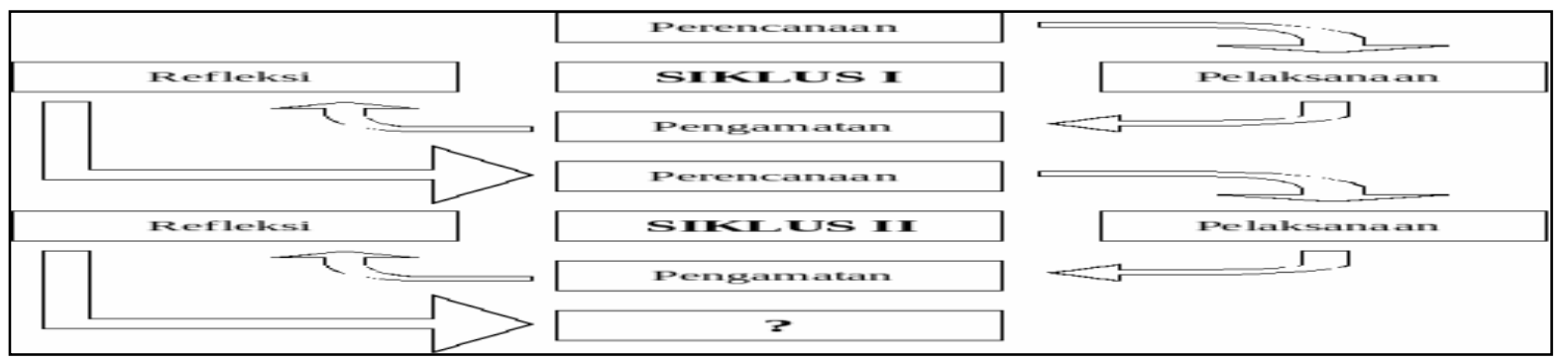

Gambar 1. Langkah-Langkah Penelitian Tindakan Kelas (PTK)

\section{HASIL PENELITIAN}

Dari data yang diperoleh dan temuan yang diperoleh maka data yang ddidapat dari hasil penelitian adalah sebagai berikut:

\section{Data Hasil Siklus I}

Hasil data pelaksanaan perbaikan pembelajaran yang dilaksanakan dengan menempuh langkah-langkah pembelajaran yang dimulai dari persiapan sarana pendukung, melakukan kegiatan awal atau pemanasan dengan melakukan gerakangerakan pelemasan pada peresendian pergelangan tangan serta tangan dan selanjutnya kegiatan inti dimana aktifitas proses belajar mengajar pada tenis meja melalui upaya 
metode bagian menunjukkan hasil yang lebih baik. Hal ini dapat dilihat pada tabel 1 dan grafik 1 .

Tabel 1. Data Hasil Perbaikan Servis Forehand Tenis Meja Siklus I

\begin{tabular}{ccccc} 
No & Interval & Kategori & Jumlah & Persentase (\%) \\
\hline 1 & $91-100$ & Sangat Kompeten & 0 & $0 \%$ \\
2 & $71-90$ & Kompeten & 0 & $0 \%$ \\
3 & $61-70$ & Cukup Kompeten & 5 & $18,52 \%$ \\
4 & $<61$ & Tidak Kompeten & 22 & $81,48 \%$ \\
\hline \multicolumn{7}{c}{ Jumlah } & $\mathbf{2 7}$ & $\mathbf{1 0 0 \%}$ \\
\hline \multicolumn{2}{c}{ Rata-Rata } & $\mathbf{0 \%}$ \\
\hline
\end{tabular}

Grafik 1. Data Hasil Perbaikan Servis Backhand Bulutangkis Siklus I

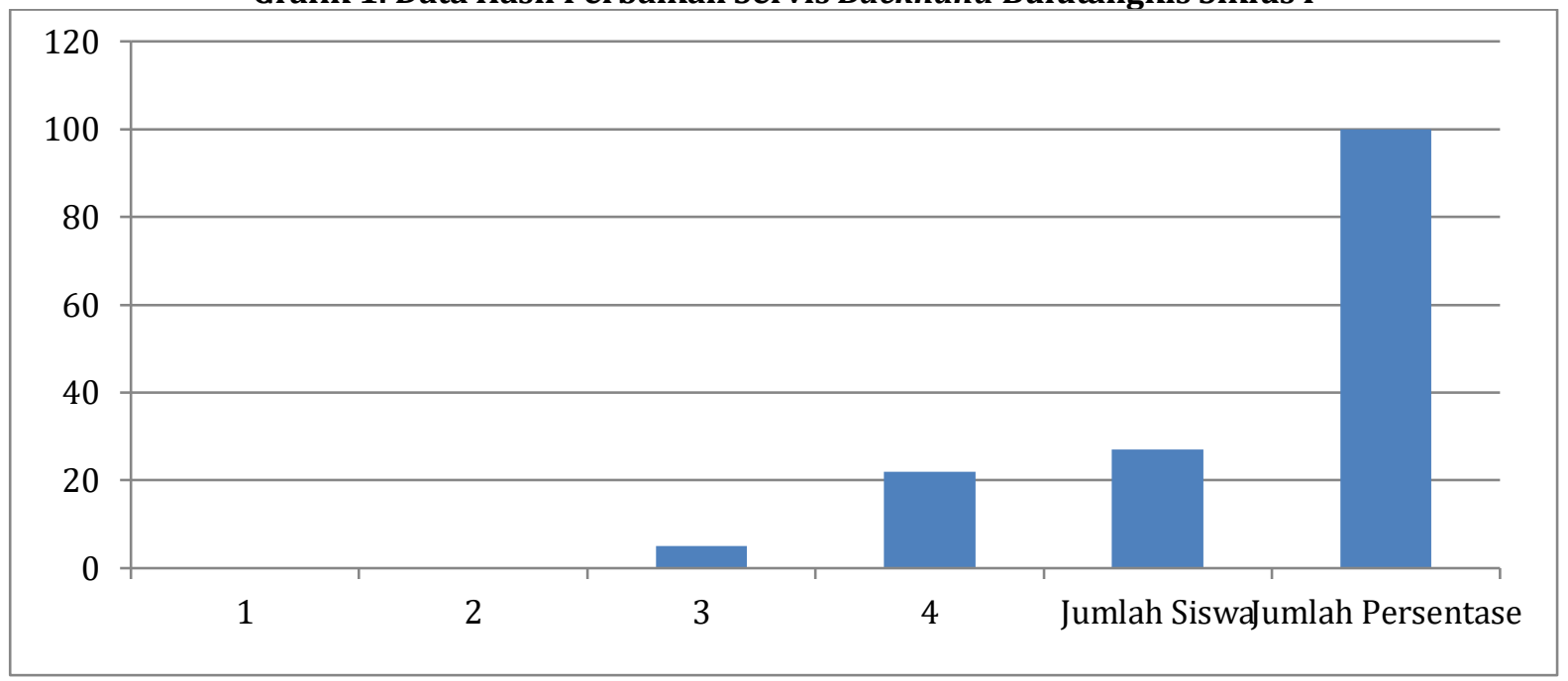

Berdasarkan data yang diperoleh dari tabel di atas, diketahui bahwa dengan upaya metode bagian pada servis forehand tenis meja pada siswa kelas VIII-1 di SMP Muhammadiyah 2 Pekanbaru yang berjumlah 27 orang sudah menunjukkan hasil yang baik dimana bertambahnya jumlah anak yang mampu mencapai atau melewati nilai acuan patokan minimal 70 maupun KKM (70) yang ditetapkan. Dari 27 orang kategori sangat kompeten 0 orang, kompeten 0 orang $0 \%$, cukup kompeten 5 orang 18,52\%, dan tidak kompeten 22 orang 81,48\%. Jadi dapat disimpulkan bahwa siswa yang menguasai teknik servis forehand tenis meja hanya 0 orang $0 \%$ sedangkan selebihnya 27 orang $81,48 \%$ yang belum berhasil.

\section{Data Hasil Siklus II}

Hasil data pelaksanaan perbaikan pembelajaran yang dilaksanakan dengan menempuh langkah-langkah pembelajaran yang dimulai dari persiapan sarana pendukung, melakukan kegiatan awal atau pemanasan dengan melakukan gerakangerakan pelemasan pada peresendian pergelangan tangan serta tangan dan selanjutnya kegiatan inti dimana aktifitas proses belajar mengajar pada tenis meja melalui upaya metode bagian menunjukkan hasil yang sangat memuaskan. Hal ini dapat dilihat pada tabel 2 . 
Tabel 2. Data Hasil Perbaikan Servis Forehand Tenis Meja Siklus II

\begin{tabular}{ccccc}
\hline No & Interval & Kategori & Jumlah & Persentase (\%) \\
\hline 1 & $91-100$ & Sangat Kompeten & 0 & $0 \%$ \\
2 & $71-90$ & Kompeten & 2 & $7.41 \%$ \\
3 & $61-70$ & Cukup Kompeten & 13 & $48,14 \%$ \\
4 & $<61$ & Tidak Kompeten & 12 & $44,44 \%$ \\
\hline \multicolumn{3}{c}{ Jumlah } & $\mathbf{2 7}$ & $\mathbf{1 0 0 \%}$ \\
\hline
\end{tabular}

Grafik 2. Data Hasil Perbaikan Servis Forehand Tenis Meja Siklus II

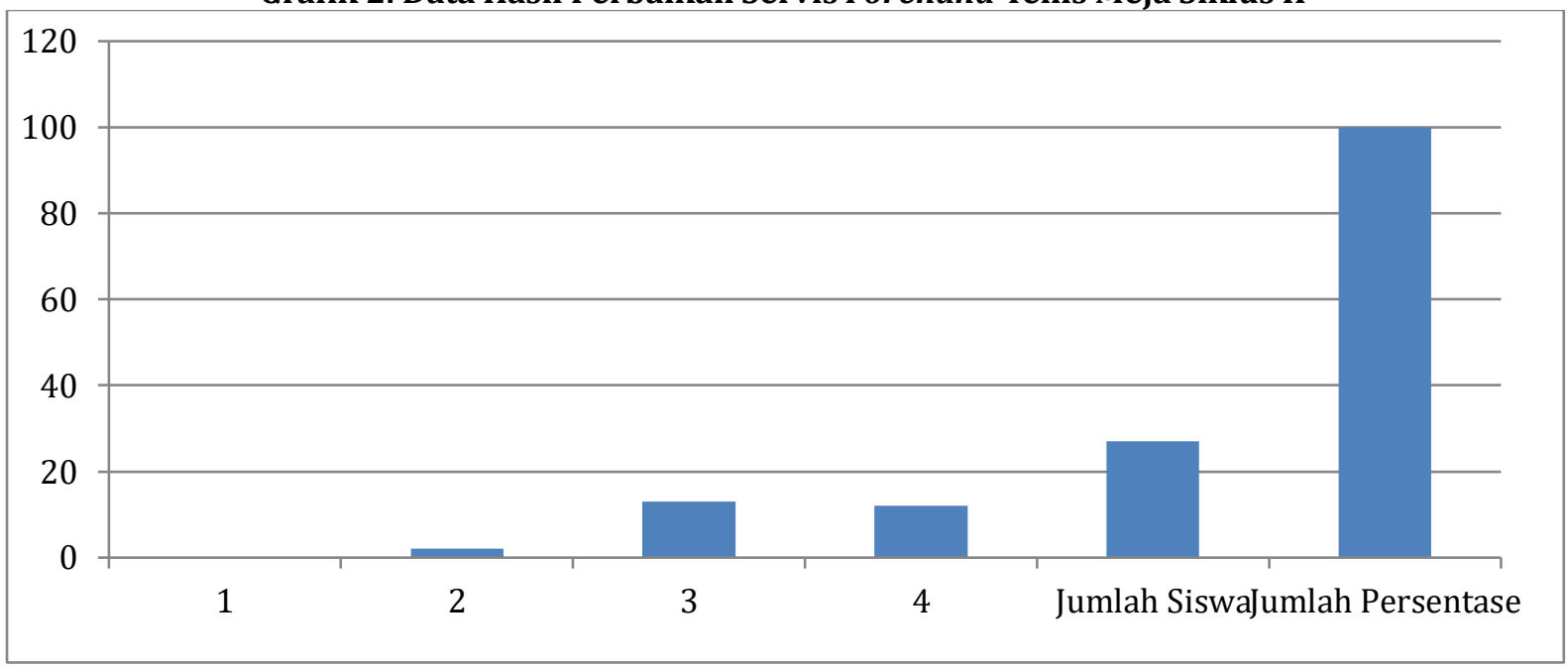

Berdasarkan data yang diperoleh dari tabel di atas, diketahui bahwa dengan upaya metode bagian pada servis forehand tenis meja pada siswa kelas VIII-1 SMP Muhammadiyah 2 Pekanbaru yang berjumlah 27 orang sudah menunjukkan hasil yang baik dimana bertambahnya jumlah anak yang mampu mencapai atau melewati nilai acuan patokan minimal 70 maupun KKM (70) yang ditetapkan. Dari 27 orang kategori sangat kompeten 0 orang $0 \%$, kompeten 2 orang 7,41\%, cukup kompeten 13 orang 48,14\%, dan tidak kompeten 12 orang 44,44\%. Jadi dapat disimpulkan bahwa anak yang menguasai teknik servis forehand tenis meja hanya 2 orang 7,41\% sedangkan selebihnya 25 orang 92,59\% yang belum berhasil. Bertambahnya jumlah anak yang mampu mencapai melewati nilai patokan minimal 70 atau nilai KKM 70, maka keberhasilan tujuan pembelajaran sebagai upaya meningkatkan teknik servis forehand tenis meja melalui metode bagian siswa kelas VIII-1 SMP Muhammadiyah 2 Pekanbaru sangat relevan dipadukan pelaksanaannya.

Berdasarkan data hasil pembelajaran, dimulai dari hasil data awal hingga melakukan perbaikan pembelajaran ke semua itu hasil pengamatan dan diskusi penulis dengan teman serta saran pihak-pihak yang ikut jalannya penelitian tindakan kelas ini. Sebagai kesimpulan akhir bahwa pembelajaran yang telah dilaksanakan sudah menunjukkan hasil yang baik, hal ini dibuktikan dengan melihat dan mengamati hasil belajar anak dalam partisipasinya saat melakukan servis forehand, baik pada perbaikan siklus I maupun siklus II. 
Tabel 3. Data Hasil Perbaikan Servis Forehand Tenis Meja, Siklus I dan Siklus II

\begin{tabular}{ccccc}
\hline \multirow{2}{*}{ No } & \multirow{2}{*}{ Knterval } & & \multicolumn{2}{c}{ Daya Serap (\%) } \\
\cline { 3 - 5 } & & Sangat kompeten & $0 \%$ & Siklus II \\
\hline 1 & $91-100$ & Kompeten & $0 \%$ & $0 \%$ \\
2 & $71-90$ & Cukup Kompeten & $18,52 \%$ & $7,41 \%$ \\
3 & $61-70$ & Tidak Kompeten & $81,48 \%$ & $48,14 \%$ \\
4 & $>61 \quad$ & $\mathbf{1 0 0 \%}$ & $\mathbf{1 0 0 \%}$ \\
\hline \multicolumn{3}{c}{ Jumah (\%) } & $\mathbf{2 7}$ & \\
\hline \multicolumn{3}{c}{ Jumlah Siswa } & $\mathbf{0 \%}$ & $\mathbf{7 , 4 1 \%}$ \\
\hline
\end{tabular}

Grafik 3. Data Hasil Perbaikan Servis Forehand Tenis Meja Siklus I dan Siklus II

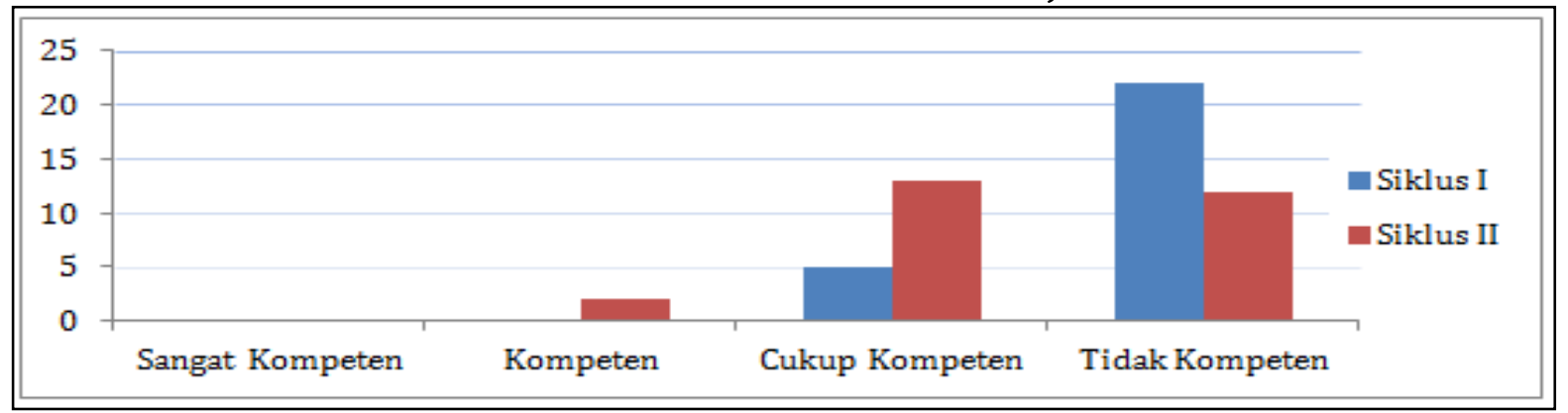

Peningkatan hasil servis siswa dari siklus I ke siklus II adalah dari data sangat kompeten 0 orang $(0 \%)$, kompeten dari 0 orang $(0 \%)$ berubah menjadi 2 orang $(7,41 \%)$ terjadi peningkatan 2 orang (7,41\%), cukup kompeten dari 5 orang $(18,52 \%)$ berubah menjadi 13 orang $(48,14 \%)$ terjadi peningkatan 8 orang $(23,53 \%)$ dan tidak kompeten 22 orang $(81,48 \%)$ berubah menjadi 12 orang (35.29\%) terjadi pengurangan 10 orang $(37,03 \%)$.

Jadi dapat disimpulkan bahwa kemajuan servis forehand tenis meja dengan menerapkan metode bagian dari siklus I ke siklus II di atas dengan berpedoman kepada acuan patokan penilaian minimal dan kriteria ketuntasan minimal, maka siswa yang berhasil dari $0(0 \%)$ orang meningkat menjadi $2(7,41 \%)$ orang sedangkan anak yang tidak berhasil dari 27 (100\%) orang berkurang menjadi 25 (92,59\%) orang.

Berdasarkan hasil yang ada di atas, maka dapat disimpulkan perbaikan pembelajaran servis forehand tenis meja dengan indikator sikap berdiri, posisi kaki, arah pandangan depan atau sasaran yang diinginkan, gerakan ayunan tangan saat memukul bola, posisi tubuh saat memukul bola, gerakan tangan saat melambungkan bola, bola melewati net dan tidak melewati net, posisi bet setelah memukul bola, kembali ke posisi awal setelah memukul bola, bola melewati net atau tidak melewati, telah berhasil melalui penerapan metode bagian.

\section{PEMBAHASAN}

Penerapan metode mengajar bagian terhadap peningkatan hasil belajar servis forehand tenis meja siswa kelas VIII1 SMP Muhammadiyah 2 Pekanbaru menunjukkan adanya sebuah peningkatan. Hal ini dibuktikan dengan melihat dan mengamati hasil belajar anak dalam partisipasinya saat melakukan servis forehand, baik pada perbaikan siklus I maupun siklus II.

Servis forehand tenis meja dengan menerapkan metode bagian dari siklus I ke siklus II di atas dengan berpedoman kepada acuan patokan penilaian minimal dan kriteria ketuntasan minimal, maka siswa yang berhasil dari $0(0 \%)$ orang meningkat menjadi 2 $(7,41 \%)$ orang sedangkan anak yang tidak berhasil dari $27(100 \%)$ orang berkurang 
menjadi 25 (92,59\%) orang. Berdasarkan dari hasil penelitian Yulianto (2016) terbukti bahwa ada pengaruh penggunaan metode bagian terhadap hasil keterampilan belajar, sama halnya dengan penelitian yang dilakukan Hidayat dan Tomoliyus (2013) yaitu ada peningkatan pada pembelajaran siklus II dibandingkan siklus I, baik dilihat dari pengelolaan kelas, maupun proses belajar mengajar menggunakan metode bagian. Penggunaan waktu lebih efektif, karena para siswa telah mendapatkan informasi lebih jelas dari guru, dan telah memperoleh pengalaman dari pembelajaran.

Seperti yang disebutkan oleh Michael dan Sudarso (2020) kelebihan dari metode bagian tersebut yaitu: (1) Siswa dapat menguasai perbagian dari materi secara baik; (2) Siswa dapat meminimkan terjadinya kesalahan, karena masing-masing bagian materi harus dikuasai baru adanya peningkatan; (3) Membangkitkan minat dan motivasi belajar siswa. Dilihat dari kelebihan tersebut, bahwa metode bagian sangat membatu siswa dalam memahami suatu pembelejaran dan membuat siswa lebih bisa menguasai pembelajaran tersebut secara lebih baik.

\section{KESIMPULAN}

Berdasarkan hasil analisis data dan pembahasan, maka dapat ditarik kesimpulan sebagai berikut: penerapan metode mengajar bagian dapat meningkatkan hasil belajar servis forehand tenis meja siswa kelas VIII1 SMP Muhammadiyah 2 Pekanbaru. Metode bagian dapat membangkitkan minat dan motivasi belajar siswa. Metode bagian sangat membatu siswa dalam memahami suatu pembelejaran dan membuat siswa lebih bisa menguasai pembelajaran tersebut secara lebih baik. Penggunaan waktu pada metode bagian lebih efektif, karena para siswa telah mendapatkan informasi lebih jelas dari guru, dan telah memperoleh pengalaman dari pembelajaran. Berdasakan temuan penelitian ini, diharapkan guru pendidikan jasmani bisa menjadikan metode bagian salah satu solusi dalam meningkatkan keterampilan servis forehand tenis meja.

\section{DAFTAR PUSTAKA}

Arikunto, S. (2015). Penelitian Tindakan Kelas. Depok: PT Rajagrafindo Persada.

Giriwijoyo, H.Y.S. (2012). Ilmu Faal Olahraga. Bandung: FPOK UPI.

Haris, I. N. (2018). Model Pembelajaran Peer Teaching dalam pembelajaran Pendidikan jasmani. Biomartika: Jurnal Ilmiah Fakultas Keguruan dan Ilmu Pendidikan, 4(1), 1118.

Harsono. (2015). Teori dan Metodologi Kepelatihan Olahraga. Bandung: Remaja Rosda Karya.

Hasrion., Sari, M., \& Gazali, N. (2020). Penelitian Tindakan Kelas: Meningkatkan kemampuan teknik dasar shooting sepakbola melalui metode bagian. Edu Sportivo: Indonesian Journal of Physical Education, 1(1), 16-24. https://doi.org/10.25299/es:ijope.2020.vol1(1).5119.

Hidayat, M., \& Tomoliyus. (2013). Upaya Peningkatan Pembelajaran Lompat Jauh Gaya Menggantung dengan Metode Bagian Progresif Siswa SMAN 1 Ceper. Jurnal Keolahragaan, 1(1), 84-103. 
Huang, H, H., Hsueh, Y,. C., Chen, Y. Y., Chang, T. J., Pan, K. M., Huang, K. S., \& Tsai, C. L. (2012). The dynamical analysis of table tennis forehand and backhand drives. In ISBSConference Proceedings Archive (pp. 3-6).

Juniarisca., D., \& Andrijanto., D. (2017). Permainan Tenis Meja. Surabaya: Unesa University Press.

Mahendra, I. R., Nugroho, P., \& Junaidi, S. (2012). Kelentukan Pergelangan Tangan dan Koordinasi Mata Tangan Dalam Pukulan Forehand Tenis Meja. Journal of Sport Science and Fitness, 1(1), 11-16.

Michael., S, C. \& Sudarso (2020). Pengaruh Penerapan Metode Bagian Terhadap Hasil Belajar Keterampilan Lompat Kangkang. Jurnal Pendidikan Olahraga dan Kesehatan, 8(1), 77-80.

Mubarok, H. (2015). Analisis Profil Tingkat Kesegaran jasmani pemain futsal Anker FC Tahun 2014. Skripsi. Universitas Negeri Semarang.

Muhdyaharjo, R. (2012). Pengantar Pendidikan. Jakarta: Rajawali Pers.

Nurfajrin, Y. (2014). Pengaruh Penerapan Model Pembelajaran Kooperatif Tipe Numbered Head Together (NHT) Terhadap Hasil Belajar Dribbling Sepakbola (Studi Pada Siswa Kelas XI SMA Negeri 1 Tarik Sidoarjo). Jurnal Pendidikan Olahraga dan Kesehatan, 2(2), 481-484.

Prastowo, G. (2014). Pengaruh Metode Pembelajaran Part Practice Terhadap Hasil Belajar Shooting Bola Basket (Studi Pada Siswa Kelas XI-IPS SMA Negeri 1 Cerme. Jurnal pendidikan olahraga dan Kesehatan, 2(3), 747-749.

Putro, B, L. (2016). Perbandingan Metode Part Practice Dengan Metode Whole Practice Dalam Pembelajaran Shooting Bola Basket. Jurnal Pendidikan Olahraga dan Kesehatan, 3(2), 586-590.

Reza, A., \& Kartiko, D, C. (2019). Pengaruh Modifikasi Permainan Colours Paper Terhadap Keterampilan Pukulan Forehand Tenis Meja. Jurnal Pendidikan Olahraga dan Kesehatan, 7(2), 171-174.

Sari, D. N., \& Antoni, D. (2020). Analisis kemampuan forehand drive atlet tenis meja. Edu Sportivo: Indonesian Journal of Physical Education, 1(1), 60-65. https://doi.org/10.25299/es:ijope.2020.vol1(1).5253.

Suryani, S. (2017). Pengaruh Penggunaan Metode Bagian (Part Method) Terhadap Hasil Belajar Dribble Bola Basket. Jurnal Pendidikan Olahraga dan Kesehatan, 5(1), 102109.

Taufik, M., S., \& Gaos, M., G. (2019). Peningkatan Hasil Belajar Dribbling Sepakbola Dengan Penggunaan Media Audio Visual. Jp.jok (Jurnal Pendidikan Jasmani, Olahraga dan Kesehatan), 3(1), 43-54. https://doi.org/10.33503/jp.jok.v3i1.540. 
Widiyatmoko, F. A., \& Hudah, M. (2017). Evaluasi Implementasi Pendidikan Nilai Dalam Pembelajaran Penjas. Jurnal Ilmiah Penjas (Penelitian, Pendidikan dan Pengajaran), 3(2), 44-60.

Yulianto, P. F. (2016). Perbedaan Pengaruh Pendekatan Pembelajaran Metode Bagian dan Keseluruhan Terhadap Peningkatan Dribble Shooting Sepakbola Ditinjau Dari Koordinasi Mata-Kaki (Studi Eksperimen Pada Mahasiswa Pembinaan Prestasi Sepakbola Fakultas Keguruan dan Ilmu Pendidikan. Jurnal Ilmiah SPIRIT, 16(1), 1429. 